\title{
Environmental investment as a factor of sustainable economic development in the context of transformation of the external and internal environment
}

\author{
Ekaterina Sheina ${ }^{1}{ }^{*}$, Aleksandr Kurdyumov ${ }^{1}$, and Maria Zavyalova ${ }^{1}$ \\ ${ }^{1}$ Ural State University of Economics, 8 Marta str. 62/45, 620144 Yekaterinburg, Russian Federation
}

\begin{abstract}
The desire to avoid dependence on the principles of the commodity economy, as well as the ultimate exhaustion of natural resources, encourages the state and business to search for new mechanisms and technologies for the reproduction of public goods. One of the key dominants in this direction is the field of ecology, environmental conservation, and, as a result, the development of environmental investment projects. However, the new investment principles require not only sustainable interest of investors and economic entities, but also an extensive developed legislative framework, protective mechanisms for reducing investment risks and highquality financial regulation of this process by the state. The development of environmental investment will contribute to the sustainable growth of the Russian economy in the context of the transformation of the external and internal environment, the general improvement of the environmental friendliness of the production of national goods and services, and will also allow to establish an alternative direction of green financing.
\end{abstract}

\section{Introduction}

In the changing realities of the modern world, the problems of ecology, exhaustion of resources and preservation of pristine wilderness come to the fore in most national economies of the world. Particular attention is paid to issues of environmental pollution, the search for resource-dependent sources of reproduction of public goods, biodiversity reduction, ozone depletion, global warming. Interest in environmental conservation has been growing since the beginning of the 1970s (Table 1).

The development of a green economy is becoming a priority in the world. The recovery of the world economy from the pandemic will largely benefit environmental projects. Investments in environmental projects can create not only positive economic, but also social, psychological and cultural effects. Investments in environmental initiatives allow to introduce innovative technologies in the economy, reduce industrial emissions of enterprises, make products of higher quality, improve the image of entire corporations and industries, increase exports, and improve the well-being of the country's population.

\footnotetext{
*Corresponding author: shekat@mail.ru
} 
Many of the serious environmental problems, facing the world community, cannot be articulated at the level of an individual state or industry. [12] Existing environmental problems are inherently transboundary and can be addressed through the adoption of strategies with coordinated measures and actions at the regional, national and European levels [14]. The development and implementation of Green Transformation Roadmaps will allow to complete industrial restructuring and lower technology costs, contributing to the green transformation process [19].

Table 1. List of global events on environmental issues

\begin{tabular}{|c|l|l|}
\hline Year & \multicolumn{1}{|c|}{ Event } & \multicolumn{1}{|c|}{ Problem } \\
\hline 1974 & Conference in Bucharest & Environmental protection \\
\hline 1977 & $\begin{array}{l}\text { United Nations Conference, Mar del Plata, } \\
\text { Argentina }\end{array}$ & World water use \\
\hline 1980 & $\begin{array}{l}\text { Conference of the International Union for } \\
\text { Conservation of Nature in Ashgabat }\end{array}$ & World conservation strategy \\
\hline 1981 & Conference, held in Nairobi, Kenya & $\begin{array}{l}\text { Renewing energy sources, World } \\
\text { Charter for Nature }\end{array}$ \\
\hline 1983 & $\begin{array}{l}\text { Report "Our Common Future", the UN } \\
\text { World Commission }\end{array}$ & $\begin{array}{l}\text { Impact of environmental damage on the } \\
\text { life of the future generation }\end{array}$ \\
\hline 1992 & $\begin{array}{l}\text { United Nations Conference, Rio de Janerio } \\
\text { (document «Agenda 21») }\end{array}$ & $\begin{array}{l}\text { Balance between economic development } \\
\text { and environmental protection }\end{array}$ \\
\hline 1997 & $\begin{array}{l}\text { United Nations Conference "Rio 5+", New } \\
\text { York }\end{array}$ & $\begin{array}{l}\text { Outcomes of the five-year transition to } \\
\text { sustainable development }\end{array}$ \\
\hline 2012 & United Nations Conference "Rio 20 +" & Global problems \\
\hline 2015 & United Nations Summit, Paris & Energy problems \\
\hline
\end{tabular}

Many countries have policies aimed at preserving and improving the environment and modernizing environmental legislation. For example, in Japan, South Korea, Germany, China and other countries, support for environmental projects is provided by both public and private investments $[11,16,18]$.

The Russian Federation currently lacks free sources of financing, which hinders the development of environmental initiatives. In this regard, the search and attraction of investors who are ready to invest in environmental projects is of great importance in the Russian Federation. However, Russian legislation lacks a clear approach to regulating environmental investment. For the Russian Federation, this direction in the transition to a green economy is new and understudied in terms of the country specifics. Therefore, currently the key goal is to study the features of environmental investment in foreign countries and the opportunity to adopt the best investment experience in this area.

\section{Materials and methods}

The study is based on the provisions of investment theory and management theory, and a problematic approach that takes into account the complexity of raising funds at all stages of the life cycle of small and medium-sized enterprises of all industries and forms of ownership, especially in the context of socially oriented investment projects, including environmental investment projects, and the related need to minimize financial risks.

The study materials include data from the official website of the Federal State Statistics Service of the Russian Federation, individual data from corporate reports with state participation, as well as scientific works of Russian and foreign economists.

In the process of research, the authors use methods of dialectical, causal and structurallogical analysis, which allow us to streamline the theoretical aspects of environmental investment as a possible tool for alternative business financing in the Russian Federation in 
order to achieve the trajectory of sustainable economic development in the post-pandemic period.

The study hypothesis is based on the idea of the relationship between the principles of environmental investment and the development of new resource-saving technologies, which will ensure sustainable development of the Russian Federation economy and stable financing of economic entities implementing socially oriented investment projects, in particular in the field of ecology and environmental conservation.

\section{Empirical model}

The concept of environmental investment activities: Analysis of Russian and foreign literature on approaches to defining the term "environmental investment " allows us to systematize the existing points of view and categorize them into five groups (Table 2).

Table 2. Approaches to the definition of "environmental investment"

\begin{tabular}{|c|l|l|}
\hline No. & \multicolumn{1}{|c|}{ Authors } & \multicolumn{1}{|c|}{ Definition } \\
\hline 1 & $\begin{array}{l}\text { Kryuchkova O.M., Guzenko A.D., Gushchina E.G., } \\
\text { Badrak N.Yu.,Tarkhanova E., Fricler A., Babirina N. }\end{array}$ & $\begin{array}{l}\text { Reducing the negative } \\
\text { environmental burden }\end{array}$ \\
\hline 2 & $\begin{array}{l}\text { Egorova D.A., Sedash T.N., Tyutyukina E.B., Lobanov } \\
\text { I.N., Miroshnichenko O.S., Mostovaya N.A. }\end{array}$ & Ensuring environmental safety \\
\hline 3 & $\begin{array}{l}\text { Spiridonova A.V., Rakov I.D., Polonik S.S., Khorobrikh } \\
\text { E.V., Litvinchuk A.A., Loiseau E., Saikku L., } \\
\text { Antikainen R., Droste N., Hansjurgen B., Pitkanen K., } \\
\text { Tomsen M. }\end{array}$ & Ensuring economic benefits \\
\hline 4 & Masserov D.A., Kolpakov N.S., Falcone P.M. & $\begin{array}{l}\text { Development and modernization } \\
\text { of production }\end{array}$ \\
\hline
\end{tabular}

Taking into account the above, the authors believe that it is necessary to combine views and formulate the following definition: Environmental investment - investments aimed at reducing the negative burden on the environment in order to achieve environmental safety in the country by supporting environmental initiatives related to the modernization of production with a positive socio-economic effect.

The main vehicles of environmental investment include issuing securities, lending, microfinancing, receiving grants and subsidies, environmental taxes. Environmental investment in foreign countries is carried out in the form of subsidies, tax deductions (Table $3)$.

Table 3. Sources of ecological investment

\begin{tabular}{|l|l|}
\hline \multicolumn{1}{|c|}{ Investment source } & \multicolumn{1}{c|}{ Germany } \\
\hline \multicolumn{2}{|c|}{ Impact } \\
\hline Toxic waste tax & $\downarrow$ toxic wastes by 30\% a year \\
\hline $\begin{array}{l}\text { Environmental fee for entry } \\
\text { into ecological zones }\end{array}$ & $\downarrow$ exhaust gasses by $40 \%$ \\
\hline Subsidies for green energy & $\uparrow$ renewable energy sources by 30\% \\
\hline Environmental payments & charged after environmental intervention (e.g. landscape change) \\
\hline Concessional lending & green projects investment \\
\hline \multicolumn{2}{|c|}{ Denmark } \\
\hline Waste charges & \multicolumn{1}{c|}{ Canada } \\
\hline \multicolumn{2}{|c|}{ Recycling } \\
\hline "Green" bonds & $\begin{array}{l}\text { Construction of green stations for electric vehicles, support for } \\
\text { environmental initiatives }\end{array}$ \\
\hline \multicolumn{2}{|c|}{ Greece } \\
\hline
\end{tabular}




\begin{tabular}{|l|l|}
\hline Water tax & Reduced water consumption \\
\hline Plastic bag tax & $\downarrow$ plastic wastes by $40 \%$ \\
\hline Subsidies & Purification of water when it is delivered by organizations \\
\hline \multicolumn{2}{|c|}{ Sweden } \\
\hline $\begin{array}{l}\text { Tax on carbon, ethyl gasoline, } \\
\text { diesel fuel }\end{array}$ & $\downarrow$ carbon pollution by $6 \%, \downarrow$ pollution from motor vehicles by $75 \%$ \\
\hline \multicolumn{2}{|c|}{ Japan } \\
\hline $\begin{array}{l}\text { Payments for extraction of } \\
\text { water from rivers, use of water }\end{array}$ & Costs are covered by payments for maintaining water quality \\
\hline \multicolumn{2}{|c|}{ Russia } \\
\hline State programmes & Support for ecological projects \\
\hline
\end{tabular}

Table 4 provides a comparative analysis of the use of different sources of financing to stimulate and develop environmental projects in foreign countries.

Table 4. Comparison of environmental investment sources in Russia and foreign countries

\begin{tabular}{|c|c|c|c|c|c|c|}
\hline Country & 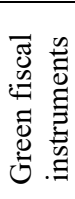 & 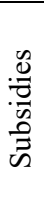 & 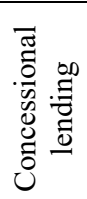 & 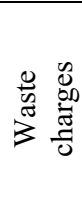 & 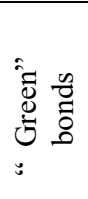 & 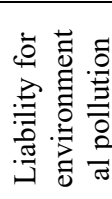 \\
\hline Greece & * & * & & * & & \\
\hline Denmark & $*$ & * & $*$ & & $*$ & \\
\hline Germany & * & * & * & $*$ & & \\
\hline Sweden & * & * & * & * & & \\
\hline Canada & * & * & * & * & $*$ & $*$ \\
\hline Russia & $*$ & * & & * & & \\
\hline Japan & $*$ & * & * & * & $*$ & \\
\hline
\end{tabular}

To ensure Russia's sustainable development, the list of environmental investment instruments should be expanded.

\section{Results and discussions}

In the period from 2010-2020 in the Russian Federation there was an increase in environmental investment, the value of which varied from 102.39 billion rubles. up to 168 billion rubles. This trend is associated with the deterioration of the environmental situation among large national corporations, some of which are beginning to develop and implement environmental programs.

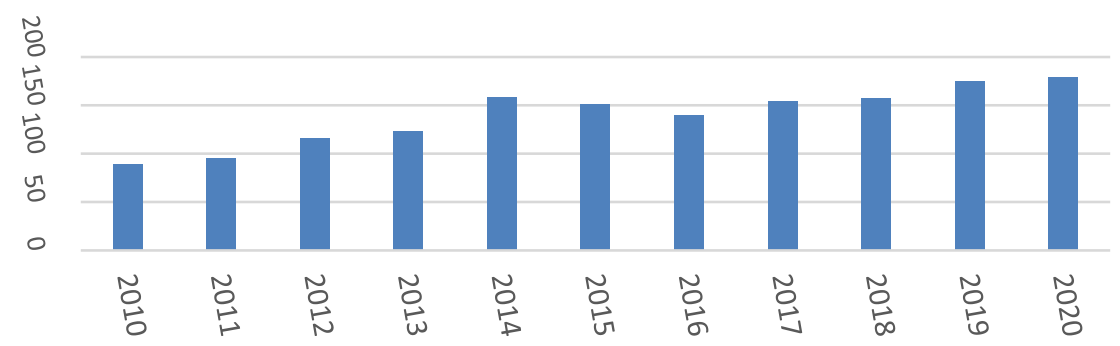

Fig. 1. Dynamics of environmental investment in Russia, 2010-2020, in billion rubles [20] 
Environmental investment can be divided into financing raised from public funds, private funds and other sources. Figure 2 shows the trend of environmental investment development in the Russian Federation. Over the last 10 years, investment of environmental projects at the expense of the state decreased from $26.7 \%$ in 2010 to $9.1 \%$ in 2020 . This dynamic is contrary to the existing Western practice. As a rule, in foreign countries financing by state funds makes up the largest share in the structure of environmental investment.

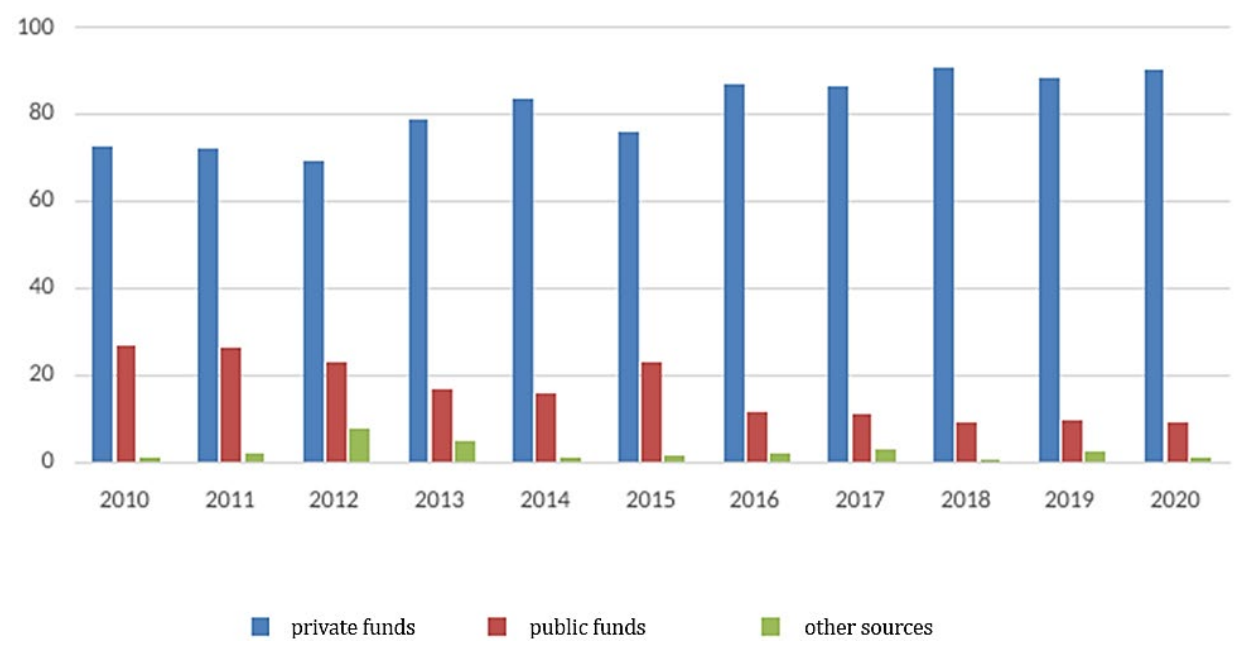

Fig. 2. Change in the structure of environmental investment in the Russian Federation from $2010-2020$, in \% [20]

The data presented in Figure 2 show that in the Russian Federation private corporations pay taxes for negative environmental impact. As a rule, the state imposes certain sanctions for violation of environmental protection. To prevent unforeseen costs for damage to nature, corporations invest in environmental projects. The growing trend in environmental investment in the Russian Federation shows a gradual transition of the country to the path of sustainable development and solving environmental problems. However, to date, there is no system for supporting environmental investment projects.

Environmental investment in the Russian Federation can be described as follows: in Russia, the most spread environmental investment instruments include co-financing, environmental lending (Table 5).

Table 5. Environmental projects, implemented in Russia

\begin{tabular}{|l|l|l|}
\hline No. & Corporation & Project title \\
\hline 1 & Lukoil Group & $\begin{array}{l}\text { Lukoil Group's Environmental Safety Program (fuel with improved } \\
\text { environmental characteristics) }\end{array}$ \\
\hline 2 & «T-Plus» PJSC & Construction of photovoltaic array (solar strata) \\
\hline 3 & Rushydro PJSC & $\begin{array}{l}\text { Construction of an Arctic wind farm in northern Yakutia with NEDO } \\
\text { Corporation (Japan) }\end{array}$ \\
\hline 4 & Sberbank PJSC & $\begin{array}{l}\text { Construction of solar and wind power plants in Nikolaev, Kherson, } \\
\text { Odessa regions }\end{array}$ \\
\hline 5 & VTB PJSC & $\begin{array}{l}\text { Cooperation with the Wildlife Foundation for the conservation of snow } \\
\text { leopard, Amur tiger, Far Eastern leopard populations }\end{array}$ \\
\hline
\end{tabular}


\begin{tabular}{|l|l|l|}
\hline 6 & $\begin{array}{l}\text { Vnesheconombank } \\
\text { Group }\end{array}$ & $\begin{array}{l}\text { Construction of Boguchanskaya hydroelectric power station on the } \\
\text { river Angara }\end{array}$ \\
\hline
\end{tabular}

From the environmental point of view, the participation of the Russian Federation in socially oriented environmental investment projects for the transition to a green economy makes it possible : to reduce pollution, restore ecological balance and reproduce the balance of ecosystems; from the economic point of view, the attained effects can include reducing product input intensity due to recycling, improving the efficiency of economic sectors, achieving socially significant environmental indicators.

\section{Conclusions}

Given the current incentives, there are some constraints to scale up environmental investment. One of the factors hindering the transition to a green economy is the lack of support and protection of investor risks, the lack of a legislative framework for environmental investment projects.

Thus, the Russian legislation still does not resolve the issue of the concept of environmental investment and its basic principles and methods. The Federal Law "On investment activities in the Russian Federation carried out in the form of capital investments" dated February 25, 1999 No. 39-FZ does not distinguish a separate legal category "investments in the environment." The draft Federal Law "On the protection and promotion of investment and the development of investment activities in the Russian Federation" No. 828237-7 does not contain environmental investment goals.

The market for "green" bonds in the Russian Federation is just beginning to form. There is insufficient institutional experience in placing bonds to localize environmental problems. The development of the mechanism for issuing green bonds could ensure a qualitative transition to a green economy in our country. In addition, in order to attract environmental investment, a green banking mechanism should be introduced, which implies a long-term environmental policy for investments in environmental initiatives. Green banking is a soft loan for economic entities involved in investment activities in environmental projects. The mechanism could facilitate access to investment resources for environmental projects.

The Russian Federation also lacks an infrastructure institution coordinating environmental investment issues. To date, these competencies are distributed between various departments, in particular, the Ministry of Natural Resources and Ecology of the Russian Federation, the Ministry of Finance of the Russian Federation, the Ministry of Economic Development of the Russian Federation, the Central Bank of the Russian Federation, but there is no clear division of functions and understanding of the area of responsibility for environmental investment development.

Summarizing the above, it should be noted that the development of environmental investment by both investors and economic entities will allow the Russian Federation to move to a sustainable path of economic development. Green investment contributes to improving the environment, mitigating the negative effects of climate change and managing resources. However, the stimulation and development of investment support for environmental projects in the Russian Federation is possible only if the legislative norms are revised and a consistent national policy in the field of green finance is carried out.

\section{References}

1. Federal Law No. 39 of February 25, 1999 "On investment activities in the Russian Federation, carried out in the form of capital investments" 
2. Federal Law No. 828237-7 "On protection and promotion of investments and development of investment activities in the Russian Federation".

3. O.S. Miroshnichenko, N.A. Mostovaya, Finance: theory and practice, 31 (2019)

4. K.A. Nazateryan, N.V. Klimovsky, Scientific and practical electronic journal, 10, 26 (2018)

5. N.S. Kolpakov, Features of environmental investment development in Russia, 14 (2019)

6. O.M. Kryuchkova, A.D. Guzenko, Promising areas of environmental investment, 43 (2019)

7. S.S. Polonik, E.V. Khorobrikh, A.A. Litvinchuk, Bulletin of Polotsk State University, 14 (2018)

8. I.D. Rakov, Current Economic Problems, 67 (2017)

9. T.N. Sedash, E.B. Sedash, I.N. Lobanov, Directions and tools for financing green projects in the concept of sustainable economic development, 52 (2019)

10. E. Yudin, Problems of tax regulation of environmental management, Taxes, 2, 67 (2015)

11. A. Bauer, K. Menrad, Energy Research \& Social Science, 67, 101509 (2020)

12. R. Boucekkine, G. Fabbri, S. Federico, F. Gozzi, European journal of operational research, 290(1), 331 (2021)

13. P. M. Falcone, International Journal of Green Economics, 14(2), 159 (2020)

14. F. Fava, L. Gardossi, P. Brigidi, P. Moroned, D. Carosie, A. Lenzif, New Biotechnology, 61, $124(2021)$

15. E. Loiseau, L. Loiseau, R. Antikainen, N. Droste, B. Hansjürgen, K. Pitkänen, M. Thomsen, Journal of Cleaner Production, 139, 361 (2016)

16. Y. Luo, M. Salman, Z. Lu, Science of the total environment, 759, 143744 (2021)

17. E. A. Tarkhanova, Terra Economicus, 16(2), 75 (2018)

18. J. Wang, L. Wang, X. Qian, Journal of Cleaner Production, 281, 124446 (2021)

19. F. Xu, F. Cui, N. Xiang, Journal of Cleaner Production, 283, 124643 (2021)

20. Service of Russian statistics, Investments in Russia, http://www.gks.ru (2021) 